\title{
EDITORIAL \\ Challenges for agroecology development for the building of sustainable agri-food systems
}

\author{
Osvaldo Salazar ${ }^{1}$, Claudia Rojas ${ }^{1}$, Cecilia Baginsky¹, Sofía Boza ${ }^{1}$, Gabriela \\ Lankin ${ }^{1}$, Andrés Muñoz-Sáez ${ }^{1}$ Jorge F. Pérez-Quezada1, Ricardo Pertuzé1, \\ Leah L.R. Renwick ${ }^{2}$, András Székács ${ }^{3}$, and Miguel Altieri ${ }^{4}$ \\ ${ }^{1}$ University of Chile, Faculty of Agricultural Sciences. Santiago, Chile. \\ ${ }^{2}$ University of California, Department of Plant Sciences. Davis, USA. \\ ${ }^{3}$ National Agricultural Research and Innovation Centre, Agro-Environmental Research Institute. Budapest, \\ Hungary. \\ ${ }^{4}$ University of California. Berkeley, USA.
}

\begin{abstract}
O. Salazar, C. Rojas, C. Baginsky, S. Boza, G. Lankin, A. Muñoz-Sáez, J. Pérez-Quezada, R. Pertuzé, L.L.R. Renwick, A. Székács, and M. Altieri. 2020. Challenges for agroecology development for the building of sustainable agri-food systems. Int. J. Agric. Nat. Resour. 152-158. Environmental and social crises in agriculture have led to growing recognition that more ecologically sustainable and socially just food and agricultural systems are needed. This thematic number of the International Journal of Agriculture and Natural Resources gathers the papers submitted by authors who were due to be speakers at the workshop "Challenges for agroecology development for the building of sustainable agri-food systems," an OECD Co-operative Research Programme-sponsored conference. The aim of the workshop was to promote the transition from conventional agriculture towards agroecology as a science, practice and social movement through sharing the experiences of different OECD countries: Australia, Canada, Chile, Colombia, Hungary, Italy, Netherlands, Norway, Spain, Sweden and the United States. The main topics to be discussed at the workshop included i) agroecology development in OECD countries: local experiences and international collaboration; ii) agroecology as a social movement and related public policies; iii) agroecology education to promote sustainable agrifood systems; and iv) science, innovation and technologies in agroecological systems. While not a comprehensive assessment of the state of agroecology in OECD countries, this thematic number integrates diverse perspectives on some main research and policy advances and uncovers some existing gaps in agroecology practice as an approach for transitioning towards ecologically sustainable and socially just agricultural systems.
\end{abstract}

Keywords: Food security, participatory co-learning, public policies, rural development, soil security. 


\section{Introduction}

Environmental and social crises in agriculture have led to growing recognition that more ecologically sustainable and socially just agri-food systems are needed. Agroecology aims to change the paradigm of conventional agriculture towards a participatory, transdisciplinary, and action-oriented design of sustainable agroecosystems and food systems (Méndez et al., 2013). Although agroecology has been part of the sustainable agriculture movement for decades (Altieri \& Nicholls, 2017; Gliessman, 2017), after major global reports (IAASTD 2009; De Schutter 2010), and an inaugural workshop in agroecology at the United Nations Food and Agriculture Organization (FAO) (FAO, 2015) that highlighted agroecology as the path to reach agricultural sustainability, the number of academic publications in agroecology has increased exponentially (Figure 1). In order to foster advances in agroecology science in Chile, the Faculty of Agricultural Sciences at the University of Chile organized a workshop "Challenges for Agroecology Development for the Building of Sustainable Agri-food Systems" which was awarded funding by the OECD's Co-operative Research Programme in Biological Resource Management for Sustainable Agriculture Systems (CRP), whose goal is to strengthen scientific knowledge and provide relevant scientific information and advice that will inform future policy decisions related to the sustainable use of natural resources in the areas of agriculture, food, fisheries and forests.

The aim of the workshop was to discuss strategies to transition from conventional agriculture towards agroecology as a science, practice and social movement and to share the experiences of different OECD countries on such transitions. The event explored three approaches for influencing policy makers on the future development of national and/or international policies related to agroecology: sharing scientific knowledge, real case studies, and participatory action plans. Thus, the workshop focused on four topics: i) agroecology development in OECD countries considering both local experiences and international collaboration; ii) agroecology as a social movement and related public policies; iii) agroecology education to promote sustainable agri-food systems; and iv) science, innovation and technologies in agroecological systems. This thematic number

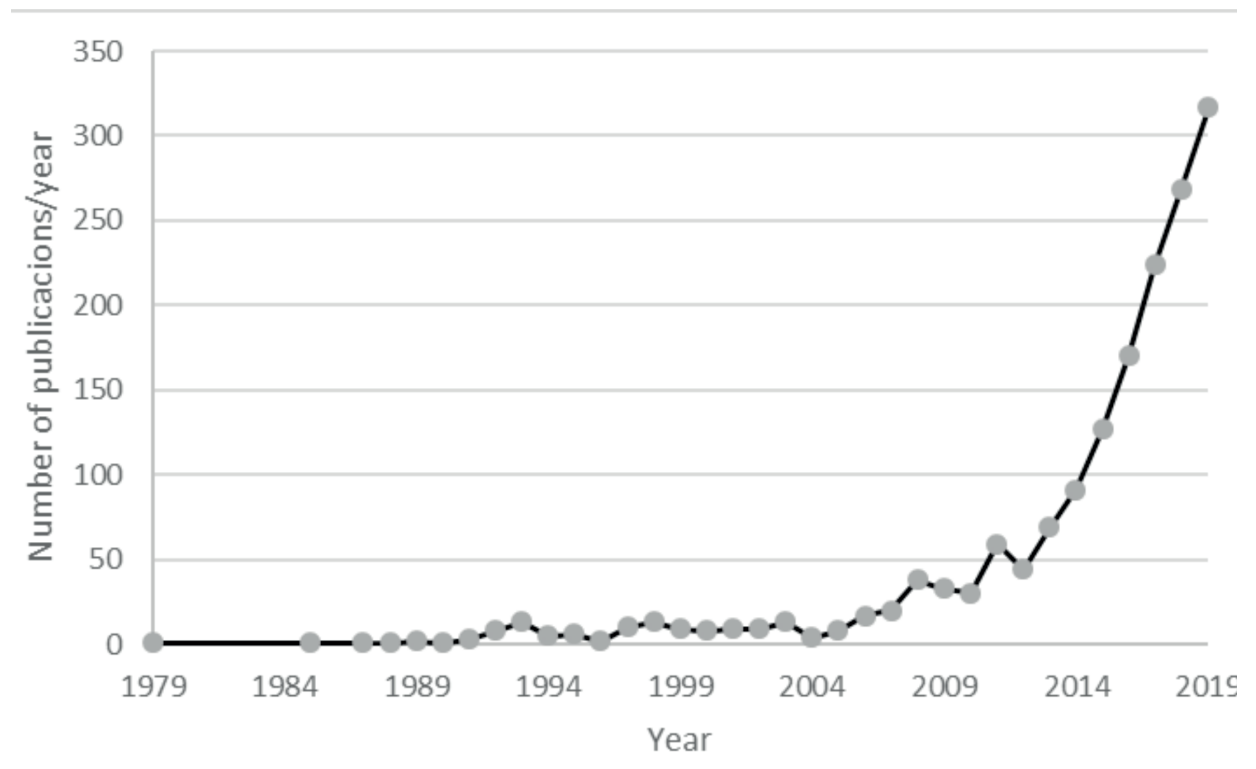

Figure 1. Evolution of the number of publications per year that include the topic agroecology in Web of Science (1979-2019). 
of the International Journal of Agriculture and Natural Resources summarizes contributions to these topics.

Description of the thematic number on agroecology

This thematic number includes 12 diverse perspectives on some major advances and gaps in agroecology practice as an approach for transitioning towards ecologically sustainable and socially just agricultural systems. While not a comprehensive assessment of the state of agroecology in OECD countries, this collection of articles includes reviews, scientific commentary pieces, and case studies reporting original research and educational program design aimed at advancing agroecological theory and practice. We have classified these contributions according to their main topics in the workshop as we describe briefly below.

\section{Agroecology development in OECD countries: local experiences and international collaboration}

Altieri and Nicholls (2020) highlight the multiple crises that humanity faces at the onset of the Anthropocene. The authors propose that these crises create a moment in which agroecology acquires greater relevance than in the past as an alternative to meet the 2030 Sustainable Development Goals and to reconstruct a post-COVID-19 agriculture. The authors provide examples using case studies from Chile, Colombia, other Latin American countries, and the Philippines.

Migliorini et al. (2020) report on a participatory open discussion process that Agroecology Europe (AEEU) has engaged in over the last three years with their members on current topics in agroecology such as: use of agrochemicals; small-scale and peasant farming versus larger farms; technological innovations in agriculture, including digitalisation, information and com- munication technologies (ICT), and precision farming; biotechnology and genetic engineering in agriculture; local and short food supply chains; social justice; and gender. The authors note that the participatory process in AEEU was not easy but served to clarify some unsettled aspects within agroecology in Europe.

Rossing et al. (2020) summarize findings from an ongoing scientific project on the different elements and relationships of the vegetable value chain in Chile and Uruguay. They investigated options for transitioning to low- or no-pesticide vegetable food systems. Their main findings are: i) a presence of promising alternative vegetable food systems in Chile, which are, however, highly marginalized and disempowered; ii) major possibilities for improving production systems by taking a system perspective at the farm scale, including farmers' families and their networks; iii) a diversity of vertical and horizontal arrangements in production in Uruguay and a need for further value-driven as well as market-driven engagement.

Székács et al. (2020) review agroecology initiatives in the Central European Region (Czech Republic, Hungary, Poland and Slovakia). They highlight a 10-fold growth of the ecological agriculture sector in the Central European Region within the last two decades, suggesting it may eventually reach in the future the EU average level. The authors discuss this shift in relation to the European institutional framework, especially the EU harmonized Rural Development Program, as well as the European Green Deal addressed in the Central European Region by the BIOEAST Strategy, and discuss several major project in the fields of research, education and social movements in the field of agroecology

Agroecology as a social movement and related public policies

González de Molina (2020) proposes that the main challenge facing agroecology is to expand the 
scale of agroecological experiences by building an alternative food system capable of challenging the hegemony of the corporate food regime. $\mathrm{He}$ argues for the formation of local, agroecologicallybased food systems that, by growing in number and scale, can impose a new institutional framework. The author makes the case that this process will only be possible through social mobilization focused not only on agricultural production and distribution, but also food consumption, to forge social alliances that promote change.

Lunner-Kolstrup (2021) presents a short communication about human and social aspects of global livestock production. She focuses on physical and psychosocial working conditions in different production systems, countries (Sweden, Germany, Uganda and USA) and cultures (Sámi indigenous people of northern Scandinavia), as well as physical and mental health in farming populations working with different types of livestock. She discusses that sustainable livestock production and global food security efforts need to address the issue of promoting sustainable, healthy, and safe working conditions to improve the physical and mental health of those working in agriculture worldwide.

\section{Agroecology education to promote sustainable agri-food systems}

Francis et al. (2020) describe participatory colearning in the Agroecology Master program at the Norwegian University of Life Science (NMBU), which exposed the challenges and opportunities perceived for students, teachers, and clients in participating in the implemention of the agricultural transformation process. The focus of the NMBU learning program is catalyzing the student's journey in developing five competencies: observation, dialogue, participation, reflection, and visioning. The authors also provide their visions on how they anticipate education will evolve in the future in order to help agroecology practitioners become agents of change through responsible actions.
Field (2020) reviews soil security as an emerging multidisciplinary concept that provides a framework with potential to support both the sustainability of the agri-food sector and other functions that soil provides. He summarizes how soil security integrates the biophysical, economic, and social dimensions that impact soil multi functionality. The author explores progress on the economic assessment of the functions that soil provides and the need to develop multidisciplinary educational strategies to improve connections between soil and end-users.

Science, innovation and technologies in agroecological systems

Jensen et al. (2020) proposed strategies for greater adoption of intercropping in European agriculture with the aim of developing more sustainable agriculture and food systems. They note that the greater adoption of intercropping in European agriculture requires solving technical, societal and knowledge challenges in crop production, understanding the long-term effects of diversification, and identifying and eliminating lock-ins and barriers against diversified cropping in agricultural systems.

Casanova et al. (2020) carried out a soil sampling survey comparing soils under industrial avocado production to those managed with agroecological practices. Using cumulative sustainability ratings for each land use, they showed that all agroecological practices constituted sustainable soil management although with high organic input requirements, while industrial avocado production was the least sustainable soil management to the extent that the authors recommended a change in land use.

Romero et al. (2020) analyze a study on the impact of an invasive insect used as a biological control agent in agroecosystems, $H$. axyridis. The authors evaluate whether $H$. axyridis is a less suitable host for D. coccinellae than $H$. variegata and $E$. 
chilensis by assessing each step in the parasitism process, from oviposition to adult emergence, in field and laboratory conditions. They conclude that in Chile, $H$. axyridis is a less suitable host for $D$. coccinellae than the native species.

Wittman et al. (2020) discuss whether a farmerdriven, bottom-up digital agriculture approach for scaling agroecology can significantly shift power dynamics between technology producers and farmers and/or between farmers with disparate access to capital and technology. They provide early insights on whether and to what extent an open-source and open-access model for digital agroecology can open new pathways for local organizations to create place-based spin-offs that include marketing components, culturally specific indicators and certification frameworks, and other opportunities for digital innovation and communication.

\section{Conclusions}

This thematic number presents different proposals and evidence to encourage the transition from conventional agriculture towards agroecology as a science, practice and social movement in OECD countries with the aim of helping develop and promote ecologically sustainable and socially just food and agricultural systems. Case studies presented in this thematic number reiterate existing scientific literature that agroecological practices such as cover cropping, intercropping and biological control promote sustainable agriculture with specific positive impacts on biodiversity and soil quality. Articles also covered ongoing and emerging topics in agroecology that merit further discussion in future meetings such as soil security, gender equality, and physical and psychosocial working conditions of farmers and farmworkers.

Looking forward, this thematic number collectively proposes that transitions toward agroecology should consider diversification of both vertical and horizontal arrangements in agroecology produc- tion and a need for further value-driven as well as market-driven engagement in OECD countries, in which food consumers and local communities forge social alliances with farmers that promote agroecological food systems. Advances can be sped up by developing educational strategies for training the next generation of agroecologists, farmers, and practitioners who will be key actors in transitioning from conventional agriculture to agroecology in OECD countries. Those strategies might include participatory co-learning across farmer training and undergraduate and postgraduate agroecology courses and programs. During this process, networks between different stakeholders who are transitioning towards agroecology should be fostered in order to promote change in the current agri-food system.

Numerous gaps related to ongoing unresolved debates in agroecology merit further discussion, namely digital agriculture and biotechnology and genetic engineering in agroecology. Digital agriculture may provide opportunities for advancing environmental sustainability without reinforcing social disparities if open-source and open-access models for developing digital agroecology tools to understand complex processes in agroecosystems are used. Biotechnology and genetic engineering area are among the most controversial topics in agriculture today that and tend to be at odds with agroecology aims due to a lack of agreement on impacts on biodiversity and environmental sustainability and consumer concern about human health effects.

Based on the contributions of experts from different OECD countries to this thematic number, we conclude that agroecology can contribute toward achieving several 2030 Sustainable Development Goals (i.e. zero hunger, climate action and life on land) and building sustainable agri-food systems. Future research in agroecology should seek to solve technical, policy, societal and practical knowledge challenges in implementing agroecological systems in small- and large-scale farming systems across OECD countries. 


\section{Acknowledgement}

This manuscript summarizes the authors' intended contribution at the Workshop on Challenges for Agroecology Development for the Building of Sustainable Agri-Food Systems (CRP), which was due to take place at the Faculty of Agricultural Sciences, University of Chile, Santiago de Chile, on 11-13 November 2019, and which was sponsored by the OECD Co-operative Research Programme: Biological Resource Management for Sustainable Agricultural Systems. Although due to the circumstances the workshop did not take place as a physical meeting, contributions intended to be supported by the OECD CRP are published in this Thematic Issue.

\section{Disclaimer}

The opinions expressed and arguments employed in this manuscript are the sole responsibility of the authors and do not necessarily reflect those of the OECD or of the governments of its Member countries.

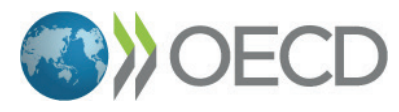

\section{Resumen}

O. Salazar, C. Rojas, C. Baginsky, S. Boza, G. Lankin, A. Muñoz-Sáez, J. Pérez-Quezada, R. Pertuzé, L.L.R. Renwick, A. Székács, y M. Altieri. 2020. Retos del desarrollo agroecológico para la construcción de sistemas agroalimentarios sostenibles. Int. J. Agric. Nat. Resour. 152-158. Las crisis ambientales y sociales en la agricultura han llevado a un reconocimiento cada vez mayor de que se necesitan sistemas agrícolas y alimentarios más sostenibles desde el punto de vista ecológico y más justos desde el punto de vista social. Este número temático de la Revista Internacional de Agricultura y Recursos Naturales reúne las ponencias presentadas por los autores que debían ser oradores en el taller "Desafíos para el desarrollo de la agroecología para la creación de sistemas agroalimentarios sostenibles", una conferencia patrocinada por el Programa de Investigación Cooperativa de la OCDE. El objetivo del curso práctico era promover la transición de la agricultura convencional a la agroecología como ciencia, práctica y movimiento social mediante el intercambio de las experiencias de los diferentes países de la OCDE: Australia, Canadá, Chile, Colombia, España, Estados Unidos, Hungría, Italia, Noruega, Países Bajos y Suecia. Los principales temas tratados en el taller incluyeron: i) el desarrollo de la agroecología en los países de la OCDE: experiencias locales y colaboración internacional; ii) la agroecología como movimiento social y las políticas públicas conexas; iii) la enseñanza de la agroecología para promover sistemas agroalimentarios sostenibles; y iv) la ciencia, la innovación y las tecnologías en los sistemas agroecológicos. Aunque no es una evaluación exhaustiva del estado de la agroecología en los países de la OCDE, este número temático integra diversas perspectivas sobre algunos de los principales avances en materia de investigación y políticas y descubre algunas lagunas existentes en la práctica de la agroecología como enfoque para la transición hacia sistemas agrícolas ecológicamente sostenibles y socialmente justos.

Palabras clave: Co-aprendizaje participativo, desarrollo rural, políticas públicas, seguridad alimentaria, seguridad del suelo. 


\section{References}

Altieri, M.A., \& Nicholls, C.I. (2017). Agroecology: a brief account of its origins and currents of thought in Latin America. Agroecology and Sustainable Food Systems 41:231-237. doi: $10.1080 / 21683565.2017 .1287147$

Altieri M.A., \& Nicholls C. I. (2020). Agroecology: Challenges and opportunities for farming in the Anthropocene. Int. J. Agric. Nat. Resour., 47(3):204-215.

Casanova, M., Ticona, B., Salazar, O., Gratacós, E., Pfeiffer, M., Ávila, G., Tapia, Y., Seguel, O., \& Sabaini, C. (2020). Physical assessment of a Mollisol under agroecological management in the Quillota Valley. Mediterranean Central Chile. Int. J. Agric. Nat. Resour., 47(3): 261-279.

De Schutter, O. (2010). Agroecology and the right to food. Report presented to the Human Rights Council A/HRC/16/49, sixteenth session. New York, USA, United Nations. Retrieved from: http://www.srfood.org/images/stories/pdf/ officialreports/20110308_a-hrc-16-49__ agroecology_en.pdf

FAO. (2015). Agroecology for food security and nutrition. Proceedings of the FAO international symposium. 18-19 September 2014. Rome. Retrived from http://www.fao.org/3/a-i4729e.pdf

Field, D. (2020). Sustaining Agri-Food Systems Framed Using Soil Security and Education. Int. J. Agric. Nat. Resour., 47(3): 249-260.

Francis C.A., Nicolaysen A.M., Lieblein G., \& Breland T.A. (2020). Transformative education in agroecology: student, teacher, and client involvement in colearning. Int. J. Agric. Nat. Resour., 47(3):280-294.

Gliessman, S. (2017). A brief history of agroecology in Spain and Latin America. Agroecology and Sustainable Food Systems 41:229-230. doi: 10.1080/21683565.2017.1292390

González de Molina, M. (2020). Strategies for scaling up agroecological experiences in the European Union. Int. J. Agric. Nat. Resour., 47(3):187203.
IAASTD (International Assessment of Agricultural Knowledge, Science and Technology for Development). (2009). Agriculture at a cross- roads: global report. B.D. MacIntyre, H.R. Herren, J. Wakhungu, R.T. Watson, eds. Washington, DC, Island Press.

Jensen, E.S., Chongtham, I.R., Dhamala, N.R., Rodriguez, C., Carton, N., \& Carlsson, G. (2020). Diversifying European agricultural systems by intercropping grain legumes and cereals. Int. J. Agric. Nat. Resour., 47(3):174-186.

Lunner Kolstrup, C. (2021). Human social aspects of global livestock production. Int. J. Agric. Nat. Resour. Under review.

Méndez, V.E., Bacon, C.H., \& Cohen, R. (2013). Agroecology as a Transdisciplinary, Participatory, and Action-Oriented Approach. Agroecology and Sustainable Food Systems 37(1):3-18. doi: 10.1080/10440046.2012.736926

Migliorini, P., Bàrberi, P., Stephane, B., Gaifami, T., Gkisakis, V.D., Peeters, A., \& Wezel, A. (2020). Controversial topics in agroecology. A European perspective. Int. J. Agric. Nat. Resour., 47(3):159-173.

Rossing, W.A.H., Groot Kormelinck, A., Alliaume, F., Dogliotti, S., Duncan, J., Huenchuleo, C., Klerkxf, L., Trienekens, J., \& Gaitán-Cremaschi, D. (2020). Transitioning to the safe and just space inside 'the doughnut' by means of agroecological niche food systems: insights from Chile and Uruguay. Int. J. Agric. Nat. Resour., 47(3):295-311.

Romero, V., Zaviezo, T., \& Grez, A.A. (2020). The invasive coccinellid Harmonia axyridis (Coleoptera: Coccinellidae) is a less suitable host for parasitism than resident species. Int. J. Agric. Nat. Resour., 47(3):312-323.

Székács, A., Roszík, P., Balázs, K., Podmaniczky, L., \& Ujj, A. (2020). Agroecology initiatives in Hungary and the Central European region. Int. J. Agric. Nat. Resour., 47(3):216-234.

Wittman, H., James, D., \& Mehrabi, Z. (2020). Advancing food sovereignty through farmer-driven digital agroecology. Int. J. Agric. Nat. Resour. 47(3):235-248. 